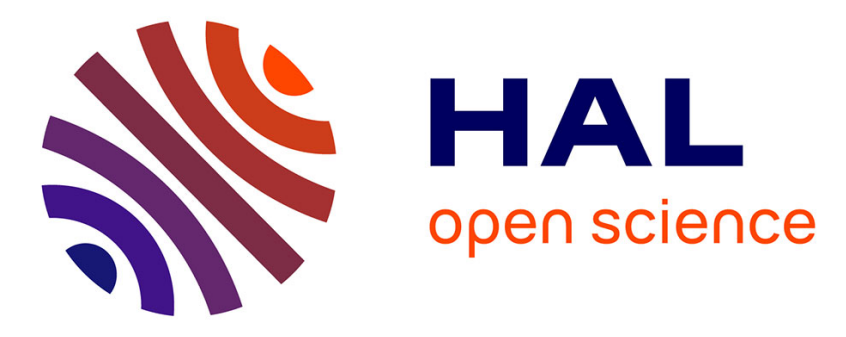

\title{
A biodiversity-employment framework to protect biodiversity
}

Jean-François Ruault, Alice Dupré La Tour, André Evette, Sandrine Allain, Jean-Marc Callois

\section{- To cite this version:}

Jean-François Ruault, Alice Dupré La Tour, André Evette, Sandrine Allain, Jean-Marc Callois. A biodiversity-employment framework to protect biodiversity. Ecological Economics, 2022, 191, pp.107238. 10.1016/j.ecolecon.2021.107238 . hal-03365820

\section{HAL Id: hal-03365820 \\ https://hal.inrae.fr/hal-03365820}

Submitted on 5 Oct 2021

HAL is a multi-disciplinary open access archive for the deposit and dissemination of scientific research documents, whether they are published or not. The documents may come from teaching and research institutions in France or abroad, or from public or private research centers.
L'archive ouverte pluridisciplinaire HAL, est destinée au dépôt et à la diffusion de documents scientifiques de niveau recherche, publiés ou non, émanant des établissements d'enseignement et de recherche français ou étrangers, des laboratoires publics ou privés. 
Ruault, J. F., la Tour, A. D., Evette, A., Allain, S., \& Callois, J. M. (2022). A biodiversity-employment framework to protect biodiversity. Ecological Economics, 191, 107238.

https://doi.org/10.1016/j.ecolecon.2021.107238

\title{
A biodiversity-employment framework to protect biodiversity
} Jean-François Ruault ${ }^{1}$, Alice Dupré la Tour ${ }^{1}$, André Evette ${ }^{1}$, Sandrine Allain ${ }^{1}$, Jean-Marc Callois

${ }^{1}$ Univ. Grenoble Alpes, INRAE, Mountain Ecosystems and Societies Laboratory (LESSEM), 2 rue de la Papeterie, BP 76, F-38402 St-Martin-d'Hères, France

Corresponding author:

jean-francois.ruault@inrae.fr

\section{A biodiversity-employment framework to protect biodiversity}

\begin{abstract}
Protecting biodiversity matters for the sustainability transition, but nothing yet seems to be able to halt the rate of biodiversity loss. The promotion of green jobs fuels questionable ideas, among which that there are green vs non-green jobs, and that the latter can be progressively replaced by green jobs. The option of developing jobs that could act to offset environmental damage is also attractive. Based on a social-ecological approach and the "strong sustainability" paradigm, the paper develops and tests a three-dimensional framework to highlight the complex and multifaceted relationship between employment growth and biodiversity enhancement. Three case studies are investigated using field expertise: slope revegetation, soil bioengineering and guided nature tours. The framework includes direct impacts of jobs on biodiversity, indirect impacts on biodiversity and ecological feedback on employment growth with two types of insights. First, it serves a reflexive analysis on the way these jobs, supposedly green, support and respond to biodiversity enhancement. Second, it helps tailor policy instruments adapted to each ideal-type of biodiversityemployment relationship towards a low biodiversity impacting economy. It highlights the various possible actions - from regulations to communication instruments - along with the types of biodiversity-employment relationships they address the best.
\end{abstract}

\section{Keywords}

green growth; social-ecological system; ecological transition; strong sustainability; avoid-reduceoffset sequence; employment policies

\section{Introduction}

In the Anthropocene, human activity is one of the major forces transforming the climate and the biosphere, leading the planet down a pathway of rapid and costly environmental degradation ${ }^{1}$. This reveals the problematic nature of the current economic paradigm and living standards of the most privileged part of humanity (Dirzo et al., 2014) - harmful to ecosystems and human health (e.g. the presence of carcinogens and endocrine disruptors in agricultural products) but weakly halted

\footnotetext{
${ }^{1}$ The TEEB (2013), for example, estimated the cost of major socio-environmental risks related to pollution and loss of ecosystem services at $\$ 7.3$ trillion a year; but this monetary estimate neglects many other immeasurable costs such as the cost to human life or multidimensional well-being.
} 
Ruault, J. F., la Tour, A. D., Evette, A., Allain, S., \& Callois, J. M. (2022). A biodiversity-employment framework to protect biodiversity. Ecological Economics, 191, 107238.

https://doi.org/10.1016/j.ecolecon.2021.107238

by their degradation. For nearly half a century, sustainable development policies have been multiplying: sustainability transitions, inclusive development, degrowth are now core issues in the academic and societal landscape. Building "a development that meets the needs of the present without compromising the ability of future generations to meet their own needs" (Brundland, 1987, p. 24) is a globally shared objective but it is subject to various interpretations, recommendations and beliefs about what sustainability really means and implies (Smith and Stirling, 2010). Currently, the dominant perspective for sustainable development policies lies in market incentives (tax, subsidies, permits...), notably business incentives (Callois, 2017; Hatt and Osawa, 2019), with a green growth horizon (Drews et al., 2019). Helm and Hepburn (2014) however recall the two other classical alternatives: command and control (e.g. protected species or areas, environment police...) and laisser-faire policies (i.e. do nothing worse). These policies compete and coexist around the world, but the ecological crisis does not seem to be on the way to being halted. The quest for social peace probably limits the means of the sustainability ambition (Levrel, 2020) and argues for a dialectic of "co-benefits", emphasized in "win-win" policies, rather than considering trade-offs between the different pillars of sustainable development.

As Bain et al. (2016) point out, the existence of co-benefits in development (i.e. economic development, scientific progress...) and benevolence (i.e. more moral and caring human community) are two important motivations to take climate action. Among these co-benefits, new (and more meaningful) jobs are often promoted (Aceleanu, 2015; Novello and Carlock, 2019). For most citizens, being part of the labour force is indeed the main, if not the only means of accessing the money or credit necessary to buy resources (goods, services, property rights, etc.) in a market economy (Ament, 2020). This gives primacy to employment in public action (Meda and Vendramin, 2016) - among which sustainable development policies. Hence, a political concern for increasing and mediatizing the number of green jobs has grown. For example, the U.S. Green New Deal, popularized at the time of the post-crisis recovery plans of 2008, promotes green growth and green job creation to tackle the ecological crisis and the climate emergency (Barbier, 2010). More recently, green jobs were among the expected co-benefits of the Nationally Determined Contributions of the 2015 Paris Agreement on climate change mitigation, adaptation and finance. In support, the International Labor Organization has repeatedly stressed that the application of the Paris Agreement would create several million new jobs by 2030 (ILO, 2018; 2019). The French Commission for Sustainable Development also estimated there were already 465,450 French jobs in the environmental sector in 2017 , representing a growth of $+5.4 \%$ since the previous year (CGDD, 2019).

The French Ministry of Ecology has also become willing to support the Avoid Reduce Compensate (ARO) sequence with a green job creation argument. The ARO sequence, in order to achieve a no net loss of biodiversity in new land transformation projects, recommends first a geographical or technical avoidance of environmental impacts, then in case of insufficiency, the reduction of impacts, and as a very last option - the compensation of impacts by ecological gains elsewhere. A varied range of new jobs are here involved, from environmental consulting firms to environmental remediation or biodiversity banking. However, not all listed jobs have the same capacity to achieve the no net loss objective. We, as a research institute, became involved in identifying and assessing the employment co-benefits of the ARO sequence, which raised many questions: to what extent does a business sector directly support or degrade - intentionally or not - the state of biodiversity? 
Ruault, J. F., la Tour, A. D., Evette, A., Allain, S., \& Callois, J. M. (2022). A biodiversity-employment framework to protect biodiversity. Ecological Economics, 191, 107238.

https://doi.org/10.1016/j.ecolecon.2021.107238

To what extent does a support or degradation occur through upstream or downstream activities? Which business sectors are sensitive to changes in biodiversity in the short term?

Considering that there is no biodiversity economics without social-ecological understanding (Helm and Hepburn, 2014), our approach relies on the social-ecological system paradigm (Berkes et al., 2000; Holling, 2001) and the "strong sustainability" paradigm (Ekins et al., 2003; Neumayer, 2003). Based on these frameworks, this article tends to distinguish jobs that are part of the ecological crisis from those that bear a solution to it.

\section{Jobs for a Biodiversity-Friendly Transition}

Green jobs have multiple definitions but are generally defined according to environmental policies (Novello and Carlock, 2019), notably the United Nations 17 Sustainable Development Goals (SDGs) for 2030 and their various adaptations (i.e. prioritization and target values) to national and regional circumstances (Neuwahl et al., 2008; Michaels and Murphy, 2009; Cai et al., 2011; Hughes, 2011; Bowen and Kuralbayeva, 2015; Elliott and Lindley, 2017; Yi, 2013; Sulich and Zema, 2018). SDGs are as various as zero hunger, climate action, gender equality or biodiversity protection (i.e. life on land and below water according to the $13^{\text {th }}$ and $14^{\text {th }}$ goals). Green jobs can then possibly concern producing goods or services with an environmental benefit (Muro et al., 2011; Pop et al., 2011; International Labour Office, 2019) as well as reducing environmental damage (Becker and Shadbegian, 2009; Morris et al., 2009; Yi, 2013; Elliott and Lindley, 2017) or ensuring direct protection and conservation of biodiversity (Beir et al., 2017). Moreover, the available data is not consistent across jurisdictions, which explains why the counting of green jobs is carried out with difficulty and on the basis of loose conventions (Sulich and Zema, 2018; Sulich et al., 2020). The lack of a common and operational green job definition is not a problem in itself; however, it has drawn attention to the technical dimensions of green job quantification, at the expense of framing hypotheses regarding Human-Nature relationships. This paper offers to step back to conceptual frameworks and introduces a green job definition, influenced by the paradigms of strong sustainability and socio-ecological systems.

\subsection{The "strong sustainability" paradigm as a counterpoint to the "green job fallacy"}

In 1850, Bastiat coined the "broken window fallacy": breaking a window gives work and pay to the glazier, but once the window repaired, the situation is equal to the one before. Although the glazier has benefited from work and pay, which sounds like "value creation", it is still the same house, and the overall utility is equal. If the window was not broken, the glazier could have used his workforce for another task and generated a net gain in utility (i.e. have improved the house). As Bastiat sums up: "Society loses the value of things which are uselessly destroyed" (Bastiat, 2007, p. 4).

Bastiat also pointed out that, "the more nature has done to effect a given result, the less there is for human labour to do", but "the cooperation of nature is essentially gratuitous - the cooperation of man [...] is essentially onerous" (ibid., p. 554). The observations of Bastiat remain actual 170 years later. Indeed, in contemporaneous societies, nature as well as future generations of human beings are excluded from the market economy. The former, nature, is made invisible, as well as the 
Ruault, J. F., la Tour, A. D., Evette, A., Allain, S., \& Callois, J. M. (2022). A biodiversity-employment framework to protect biodiversity. Ecological Economics, 191, 107238.

https://doi.org/10.1016/j.ecolecon.2021.107238

incommensurable services our societies effortless benefit from. The later, future generations, cannot - in economic terms - express its demands. Conversely, the present generation is the only one with economic agents: any demand for tradable human services means, for those producing the service, a greater participation to the market economy. Owing to this perspective, replacing the "services of nature" can be a source of economic activity, hence of job creation, more valuable than preserving ecosystems or safeguarding good living conditions for future generations.

When an activity is generated by damaging not a window but biodiversity, the problem exceeds a sole lack of utility: damages cannot be repaired identically and the nature and magnitude of consequences are uncertain (Kinzig et al., 2006). As an analogy with Bastiat, we here term "green job fallacy" the fact of welcoming jobs that respond to a trend of damage to the biosphere.

A first option to avoid such fallacy is to raise awareness of the value of nature, encouraging for instance monetization of ecosystem services (Boeraeve et al., 2015), or production of equivalence units in terms of human labour force. For example, replacing pollinating insects by human labour would cost an estimated $€ 2.3$ to $€ 5.3$ billion per year in France and more than $€ 150$ billion per year worldwide (Gallai and Vaissière, 2009; MTES, 2016). The primary goal of these estimates is to dissuade activities harmful to pollinators (e.g. chemical-intensive agriculture, building on natural or agricultural lands) and value those that favour them (e.g. organic agriculture, beekeeping). However, pricing pollination can also constitute a market opportunity for the development of manmade pollinating services, which could be qualified as biodiversity favourable where (or when) there is an absence of pollinating insects. Some companies are already developing commercial solutions for drone pollinators (Potts et al., 2018). However, the substitution of ecological resources has proven, at the least, uncertain and hazardous, in history. The mechanization of agriculture and the resulting simplification of the landscape have destroyed the habitat of valuable crop protection species (Rusch et al., 2016), requiring the massive use of artificial inputs (Robinson and Sutherland, 2002; Meehan et al., 2011). Although pesticides can be very efficient palliatives to natural pest control, these have been shown to have severe human health and ecological consequences (Beketov et al., 2013; Kim et al., 2017).

This leads us to a second option to face the green job fallacy, in which regulation completes economic incentives in order to pinpoint the jobs that provide effective biodiversity support while constraining those that are biodiversity harmful. Perverse incentives, as well as sticking-plaster solutions are especially witch-hunted. For example, the promise of ecological compensation is regularly used as a key argument to authorize an impactful project, while the effectiveness of compensation techniques is still highly uncertain (Maron et al., 2012). The control of perverse incentives is one of the Aichi Biodiversity Targets from the Strategic Plan for Biodiversity 20112020 of the Convention on Biological Diversity (CBD), a leading factor for the $2003 \mathrm{EU}$ Common Agricultural Policy reform (Schmid et al., 2007); and at the same time a remaining challenge for greening the economy (Barbier, 2016).

Our contribution relates to this second view, i.e. that not all biodiversity-related activities are equal in environmental terms, and that resting upon sole market mechanisms can lead to supporting environmentally ineffective or perverse activities. More specifically, we adopt the paradigm of "strong sustainability" and adapt it to biodiversity-employment relationships. Strong sustainability 
Ruault, J. F., la Tour, A. D., Evette, A., Allain, S., \& Callois, J. M. (2022). A biodiversity-employment framework to protect biodiversity. Ecological Economics, 191, 107238.

https://doi.org/10.1016/j.ecolecon.2021.107238

assumes that the substitution of natural capital is limited and that natural capital loss involves "risk", "uncertainty" and "ignorance" about consequences (Neumayer, 1999, p. 102). In contrast to "weak sustainability", which focus on ways to equitably pass on economic capital to future generations, coming interchangeably from nature or manufacture, "strong sustainability" emphasizes the preservation of existing natural capital and adopts a precautionary principle. "Weak sustainability" approaches may look at net emissions of $\mathrm{CO} 2$, net losses of biodiversity, or the ecological footprint of a specific product to tailor public policies. "Strong sustainability" approaches will instead focus on the actual state of biodiversity, the state of natural resources, the total amount of greenhouse effect gas in the atmosphere, or the ecological footprint of our consumption standards. Owing to a "strong sustainability" perspective, we therefore consider that the "green" category is not homogenous, and cannot qualify jobs, which enhance biodiversity on one place in one moment regardless of wider or longer-term harms to biodiversity. Absolute effects on biodiversity - including indirect effects - constitute the guiding metric for valuing jobs as more or less green.

\subsection{Highlighting social-ecological feedbacks}

Viewing human and natural systems as coupled is at the core of the "social-ecological systems" (SES) paradigm (Berkes et al., 2000; Holling, 2001; Liu et al., 2007): systems are not only interlinked but also interdependent, and even co-evolutionary on the long run. This interactive structure creates complex patterns and dynamics, especially non-linear causal effects, feedback loops and cascading effects - quasi-impossible to predict. Social-ecological systems research (Folke et al., 2007; Liu et al., 2007; Ostrom, 2011; Levin et al., 2013) attempts to provide new analytical tools to understand and envision these dynamics, but also to better measure the impact of human actions on the environment (i.e. uses, modifications, protection, etc.). Ecological economics adopts a SES view with a special emphasis on the supporting function of ecological systems and the natural environment for economic activities. Within the different facets of the "safe operating space" for human societies, biodiversity is one that draws special attention because of its critical state of degradation (Rockström et al., 2009). A first structuring observation is that there is no economic activity that does not require - at some point - the use of living resources (GeorgescuRoegen, 1993; Helm and Hepburn, 2014). A second one is that the proper functioning of ecosystems, underpinned by biodiversity (Oliver et al., 2015), performs various purification and climate regulation functions, for example, necessary to secure human living spaces (Costanza et al., 1997). In practice, however, few economic agents are sensitive to the degradation of biodiversity, so the issue of its protection is less tangible and more ideological (Levrel, 2020).

In order to promote a more effective political action of biodiversity erosion, disentangling the multiple biodiversity-employment relationships is a first step. We consider important to distinguish employment co-benefits of biodiversity enhancement from employment produced by biodiversity management. The first is an ecological positive feedback (i.e. more biodiversity leads job creation for some businesses), while biodiversity management employment simply reflects the number of jobs invested in environmental management, regardless of the state or trend of improvement/degradation of biodiversity. Within this second category of jobs lies a possible green job fallacy ( $c f .2 .1$ ). Potential negative feedbacks are also considered, in which biodiversity enhancement leads to job destruction. Some authors warn that it may not be possible to reconcile 
Ruault, J. F., la Tour, A. D., Evette, A., Allain, S., \& Callois, J. M. (2022). A biodiversity-employment framework to protect biodiversity. Ecological Economics, 191, 107238.

https://doi.org/10.1016/j.ecolecon.2021.107238

the sustainability transition with full employment (Forstater, 2006, 2004; Antal, 2014). In this case, the challenge is to reinvent the role of employment in society. One contribution of this article is to move out from an accounting logic in order to adopt a classification logic aiming at selecting relevant policy instruments.

\section{Towards a Biodiversity-Employment Framework to Tailor Biodiversity Conservation Policies}

As Vona et al. (2019) point out, while it is critical to have reliable measures of green jobs that are able to capture changes in the greening of the economy over time and across regions, definitions are often too fuzzy and the statistical infrastructure too limited. Recent studies have also attempted to move away from a static picture of green jobs to better track the greening process by counting the hours worked in biodiversity-friendly jobs, thus making it possible to reconstruct full-time equivalents and assess the level of engagement of business sectors at time $t$ (Beir et al., 2017; Vona et al., 2019). While this is a significant step forward, normative assumptions remain because the state of biodiversity is expected to progress in the same direction as related jobs, so that supporting the latter support biodiversity. Yet this expected win-win relationship does not capture the complexity of the relationships that link employment growth to changes in biodiversity. As noted by Beir et al. (2017), there can be even greater transformative powers in sectors without green jobs than in sectors with them.

\subsection{The analytical biodiversity-employment framework}

According to page 3 of the Convention on Biological Diversity (CBD), biological diversity is "the variability among living organisms from all sources including, inter alia, terrestrial, marine and other aquatic ecosystems and the ecological complexes of which they are part; this includes diversity within species, between species and of ecosystems". Biodiversity is a "global public good" (e.g. providing climate regulation for everyone) that faces threats that have no boundaries and requires global action (Helm and Hepburn, 2014); although the services provided by ecosystems and the policy required need to be adapted to local contexts (Fisher et al., 2009). Biodiversity is multidimensional and relative to scale also because an impact on one aspect or at one specific scale does not mechanistically induce a comparable impact on other aspects or scales (Pereira et al., 2013). The positive or negative impact on biodiversity of sectoral employment growth is indeed complex, especially if indirect impacts are included (Figure 1) 
Ruault, J. F., la Tour, A. D., Evette, A., Allain, S., \& Callois, J. M. (2022). A biodiversity-employment framework to protect biodiversity. Ecological Economics, 191, 107238.

https://doi.org/10.1016/j.ecolecon.2021.107238

Figure 1. The direct and indirect biodiversity-employment relationship

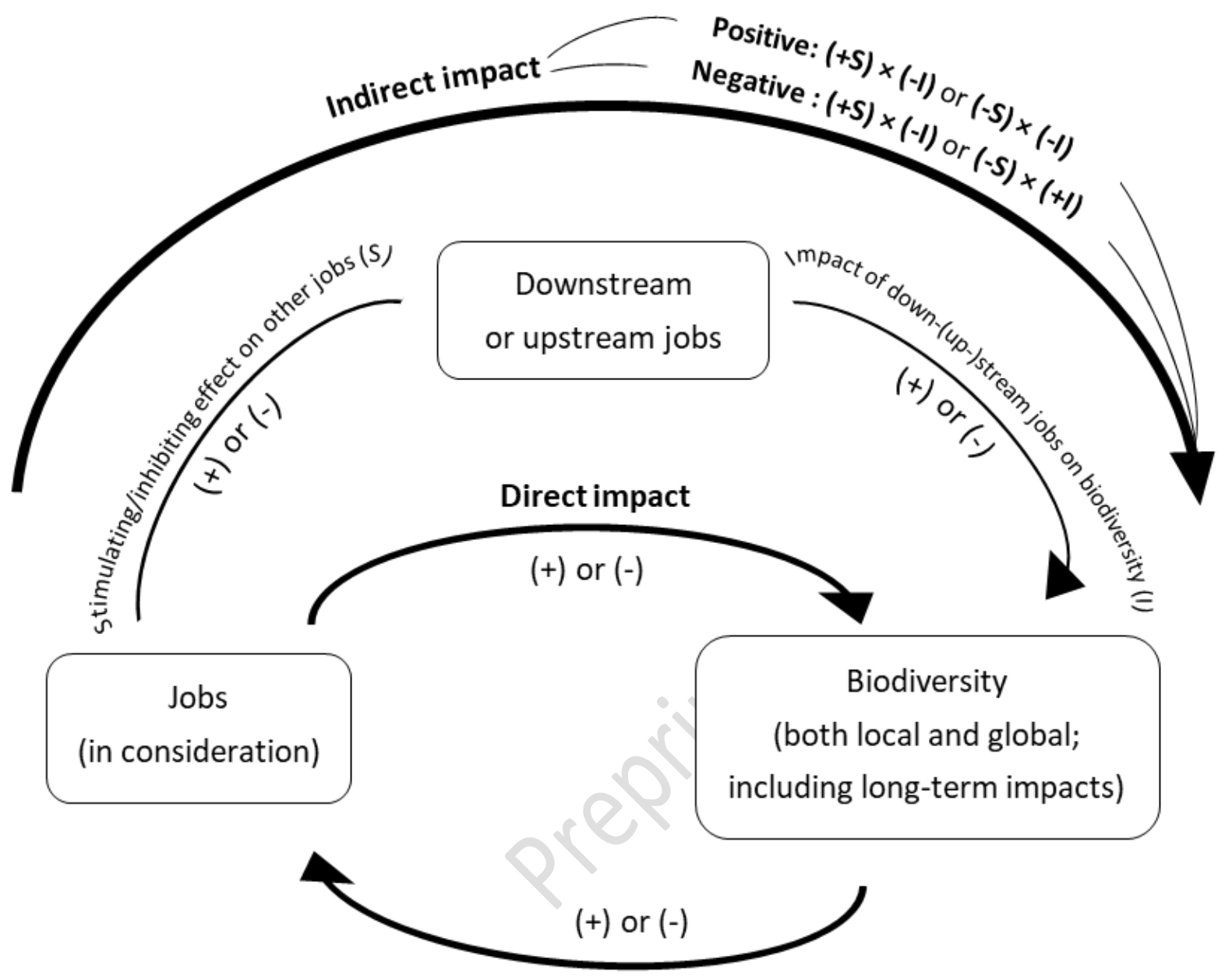

Employment feedback

The first axis of the framework (Figure 2) shows the direct impacts of employment growth on biodiversity $(y)$. The impact is considered direct if it results from the given activity alone, without possible spillover impacts. The second axis (x-axis) shows the impact of biodiversity enhancement on employment growth in the given activity $(x)$, as an ecological feedback. The colour gradient represents the indirect impact of the activity's employment growth on biodiversity, with positive impacts in red-violet and negative impacts in slate-blue. The impact is considered indirect if it derives from the causal chains that the activity contributing to fuelling by stimulating or inhibiting other jobs both upstream and downstream (see Figure 1). For example, these indirect impacts can be transfers of impacts on biodiversity to other areas or at other scales, or rewarding activities that substitute for more environmentally harmful competing activities. Employment growth is here expected to mirror the health of business activity, which assumes a constant share of labour input 
Ruault, J. F., la Tour, A. D., Evette, A., Allain, S., \& Callois, J. M. (2022). A biodiversity-employment framework to protect biodiversity. Ecological Economics, 191, 107238.

https://doi.org/10.1016/j.ecolecon.2021.107238

in the means of production ${ }^{2}$. The job ideotype labels highlight prominent figures at the extreme values of the quadrant and colour gradient to make the framework easier to read.

Figure 2. The biodiversity-employment framework with job ideotypes

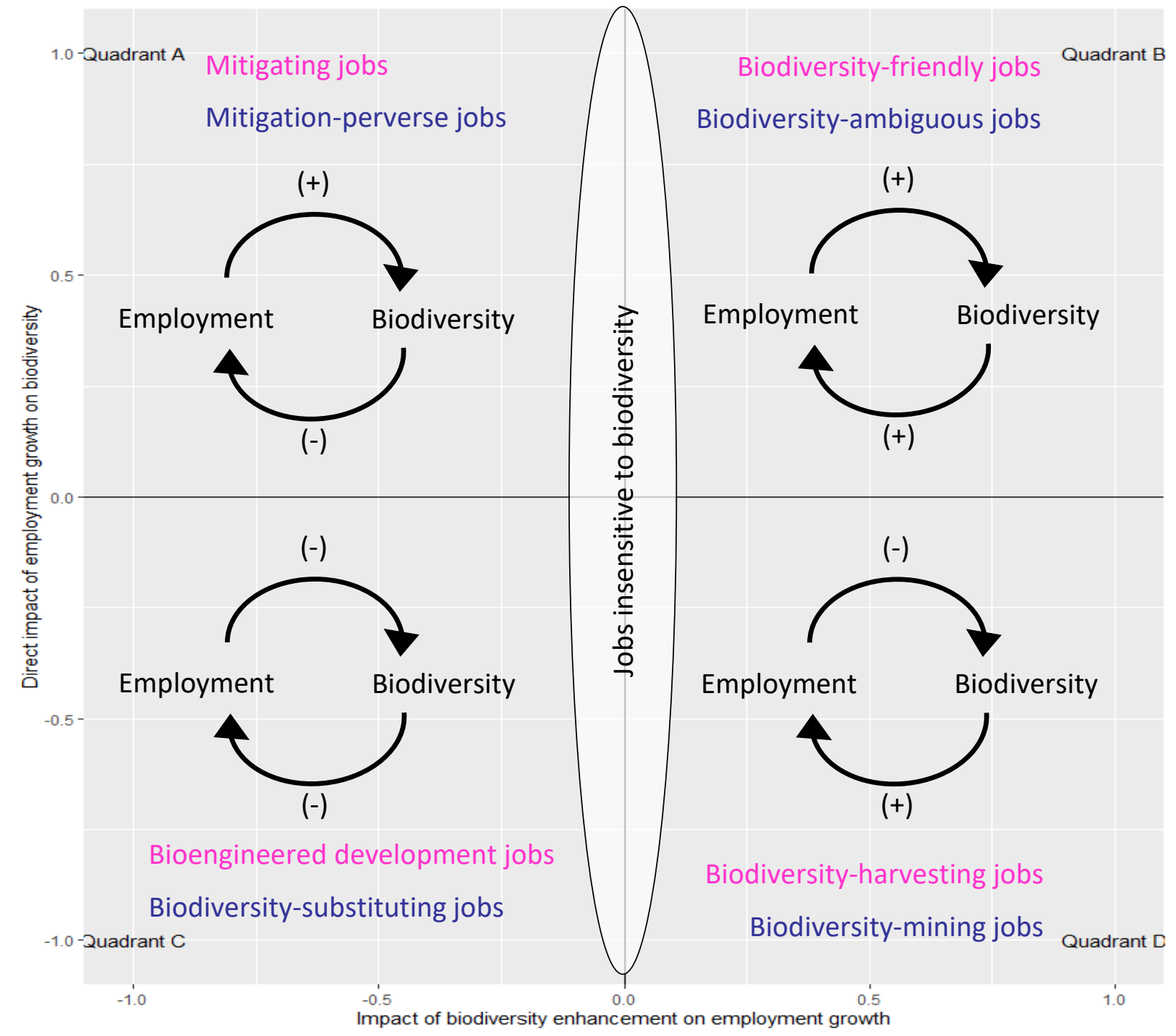

${ }^{2}$ The dialectic is relative to jobs that matter for sustainability transition, but the framework could also works for the relationship between biodiversity and gross product for example. 
Ruault, J. F., la Tour, A. D., Evette, A., Allain, S., \& Callois, J. M. (2022). A biodiversity-employment framework to protect biodiversity. Ecological Economics, 191, 107238.

https://doi.org/10.1016/j.ecolecon.2021.107238

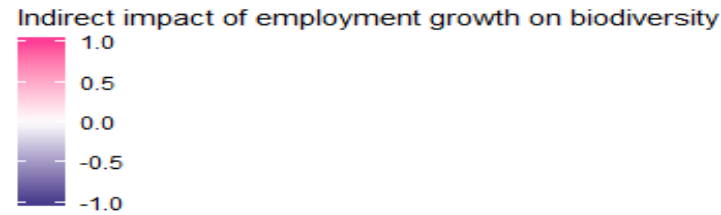

Note: The graph was created with the R package "ggplot2'.

In quadrant $\mathrm{A}$, the ideotype is jobs that mitigate biodiversity loss in a broad sense (i.e. avoid, mitigate, restore, offset...): they provide direct support to biodiversity despite a negative ecological feedback (e.g. environmental restoration ${ }^{3}$ ). When the indirect impact is negative, we talk about mitigation-perverse jobs, because the most visible impact is positive, but offset by undesirable indirect impacts, e.g. biodiversity depletion in other areas, encouragement of biodiversitydestroying projects. In quadrant $\mathrm{B}$, jobs are self-reinforcing, providing a direct positive effect on biodiversity and benefiting from it through a positive ecological feedback (e.g. extensive beekeeping). They are getting closer to the biodiversity-friendly ideotype when the apparent virtuous circle is confirmed by a positive indirect impact; otherwise they rather belong to biodiversity-ambiguous jobs, depending on the balance between positive direct impacts and negative indirect ones (e.g. intensive beekeeping). In quadrant $\mathrm{C}$, on the contrary, jobs are both harmful for biodiversity and fuelled by its depletion. This creates a vicious circle for biodiversity, which has no reason to be halted autonomously. Quadrant $\mathrm{C}$ gathers jobs we call 'biodiversitysubstitute', as they produce biodiversity-unfriendly services, which demand increases as biodiversity depletes. An example could be chemical pesticides production: this activity increases when natural pest enemies disappear, and the use of pesticides reduces insect biodiversity, including insects ensuring pest control. By substituting the loss of ecosystem services in the short or medium run, they therefore silence ecological warning signals, see for example the hidden threat of pollinator declines for crop yields (Petherick, 2008), and create territorial and/or intergenerational transfers of sustainability (Zuindeau, 2007; Potts et al., 2018). Quadrant C also integrates jobs belonging to a bioengineered development ideotype: in this case, although there is a negative direct feedback between employment and biodiversity, indirect effects counterbalance, at least partly, the vicious circle. These positive indirect effects lie in the substitute they offer to tremendously more biodiversity-harmful solutions, e.g. nature-based infrastructures instead of civil engineering. Quadrant D features jobs, which business model depends on the good state of biodiversity, hence positive social-ecological feedback, but based on biodiversity exploitation, hence direct biodiversity damages. When the indirect impact is also negative, the jobs are getting closer to a biodiversity-mining ideotype (e.g. intensive fishing), while biodiversity-harvesting jobs mitigate their direct impact with a positive indirect impact (e.g. sustainable forestry). In both cases, there is an element of self-regulation in the biodiversity-employment relationship, as the activity collapses without biodiversity. Last but not least, there is the case of jobs that are insensitive to biodiversity (i.e. no short-term ecological feedback), which are certainly the most numerous ones (Beir et al., 2017; Levrel, 2020), e.g. banking activities, digital industries, plane industries. Insensitiveness is not a synonym of no impact, and there are reasons to believe that among

\footnotetext{
${ }^{3}$ This paragraph provides examples to help explain the ideotypes but these examples should be understood as presumed.
} 
Ruault, J. F., la Tour, A. D., Evette, A., Allain, S., \& Callois, J. M. (2022). A biodiversity-employment framework to protect biodiversity. Ecological Economics, 191, 107238.

https://doi.org/10.1016/j.ecolecon.2021.107238

'biodiversity insensitive jobs' feature jobs supporting biodiversity enhancement or participating to biodiversity erosion, whether directly or indirectly.

All of these ideotypes reflect the different possible combinations of relationships between employment growth and biodiversity state (positive, negative, in both directions). Surfacing and disentangling these relationships make it possible to define policy instruments targeting employment, which would be efficient supports for the transition towards a low-biodiversityimpact economy. Policy instruments are of different kinds (Lascoumes and Gales, 2007): legislative and regulatory (e.g. prohibited business activities), economic and fiscal (e.g. ecological tax, ecological debt), agreement-based and incentive-based (e.g. fishing quotas, payment for ecosystem services), information-based and communication-based (e.g. environmental due diligence, eco-scores, ecological footprint assessments), de facto and de jure standards best practices (e.g. labelling, environmental specifications). Market incentives are far from covering the range of existing possibilities. We defend the view that policy instruments should be tailored to the biodiversity-employment relationships that characterize different jobs.

When there is a positive feedback loop, public policies should contribute to reinforcing it: not hindering the activity, supporting its economic viability if necessary, help avoid or reducing its residual impacts. Here, market incentives as well as communication instruments could be helpful for the social recognition and enhancement of biodiversity-friendly activities.

Whenever the feedback loop is negative, signing an activity with reinforcing detrimental impacts on biodiversity, the only way out is to modify the employment-biodiversity relationship (meaning structural, and probably costly, changes) or accompany the reduction of the activity to a vital minimum. This is a case where public incentives in favour of employment growth in such business sectors have much chance to turn into environmentally harmful incentives. Many 'biodiversityinsensitive' jobs, when they affect biodiversity negatively, imply the same logic of structural changes. Two joint policy recommendations can be appropriate. The first one is to impose changes using the public force (regulations and police); the second is to generate changes from the consumer side, through strong sensitization policies and information obligations.

Activities within quadrant D are theoretically self-regulatory, because a loss of biodiversity would threaten the activity. However, practice has shown, for instance, that deep-sea fisheries actually use intensive and unsustainable fishing methods with high catch rates to ensure their economic viability and - even so - many of these intensive fisheries would not survive without government subsidies (Norse et al., 2012). Settling rules of use, either through agreement-based (see the vast literature about the commons) or more traditional legislative and regulatory instruments, seems unavoidable to ensure the renewal of biodiversity resources. Non-coercive instruments targeting producers or consumers can additionally support preference changes for products, services, hence jobs ensuring a sustainable use rather than a mining logic towards biodiversity resources.

Mitigating activities imply specific employment policies for a biodiversity transition. Here the main purpose is not to modify the orientation or the magnitude of the biodiversity-employment relationships, but to implement a 'transitory' logic, which departs from a long-term employment growth outlook. Indeed, these jobs have a strategic role in a transition to a low-biodiversity impact economy, but once there, the number of jobs required should decline to a plateau from which the number of jobs should only fluctuate in response to seasonal or unusual damages. A second 
Ruault, J. F., la Tour, A. D., Evette, A., Allain, S., \& Callois, J. M. (2022). A biodiversity-employment framework to protect biodiversity. Ecological Economics, 191, 107238.

https://doi.org/10.1016/j.ecolecon.2021.107238

challenge is to help decouple the direct positive impact of these jobs on biodiversity from the job opportunity created by biodiversity erosion. One way to do so would be to ensure the independence (in decisions, authorizations, and finance) of mitigating activities from project development ones.

\subsection{Three case studies to test the framework}

To test the relevance of the biodiversity-employment framework, we applied it in three case studies in France, considering the field experience of the authors ${ }^{4}$ and the various biodiversity-employment relationships observable there. From these three case studies, five types of jobs are analyzed: (1) mountain revegetation with seeds of local origin and (2) of non-local origin, (3) guided nature tours, (4) soil bioengineering for the protection of existing riverbanks and (5) new riverbanks. In the absence of statistical measures to support the analysis, we used qualitative experts" assessments for each job. Experts (co-authors specialized in slope revegetation, riverbank protection, and tourist economy) filled in a Likert scale with values from -1 to 1 : fully negatively linked (-1), highly negatively linked (-0.75), fairly negatively linked (-0.5), slightly negatively linked $(-0.25)$, unlinked ( 0 ), slightly positively linked ( 0.25$)$, fairly positively linked $(0.5)$, highly positively linked (0.75) and fully positive linked (1).

\section{Figure 3. The biodiversity-employment relationship according to three French case studies}



${ }^{4}$ Summarizing the diversity of practices that take place in different institutional contexts (different countries, different cultures...) via Likert scores would add much uncertainty to the results. 
Ruault, J. F., la Tour, A. D., Evette, A., Allain, S., \& Callois, J. M. (2022). A biodiversity-employment framework to protect biodiversity. Ecological Economics, 191, 107238.

https://doi.org/10.1016/j.ecolecon.2021.107238

Note: The graph was created with R package "ggplot2'.

While one might be tempted to group all these activities within the category of 'green jobs', our analytical framework shows they hold different quadrant positions (Figure 3), reflecting the complex social-ecological feedbacks that mediates the relationship between biodiversity and employment.

\subsubsection{Case 1: open mountain environment revegetation with seeds of local or non-local origin}

The case study concerning revegetation focused on the revegetation of open mountain environments, i.e. altitude meadows and lawns. These environments are subject to many developments, which often leads to the destruction of plant cover. These pressures include the development of ski areas and infrastructure. To stop erosion, integrate the facilities into the landscape and restore the pastures (which are used for grazing or fodder), developers sow herbaceous seed mixtures. In restoration ecology, many studies agree on the importance of using locally sourced plants to avoid biodiversity loss (Bischoff et al., 2010; Kiehl et al., 2010; Vander Mijnsbrugge et al., 2010). However, the seeds used are usually composed of cultivars unsuitable for the bioclimatic conditions and with minimal genetic diversity (Dupré la Tour, Labatut et al. 2018). The different modes of revegetation correspond to various environmental repair efforts: while ecological restoration targets local indigenous reference ecosystems, rehabilitation targets the recovery of particular ecosystem functions or services (McDonald, Gann et al. 2016).

This case study is based on management science and ecology research carried out for several years in contexts of altitude open environments, i.e. meadows and lawns, in French alpine mountains. Our corpus consists of a survey carried out from late 2016 to early 2018 as part of the Sem'lesAlpes project and data from operational work in the development of local seeds. It gathers:

- 76 exchanges and interviews with ski area operators, transport and electricity infrastructure managers, communities, natural area managers, forest managers, biodiversity conservation bodies, scientists, engineering offices, seed producers, farmers and stakeholders in the fodder sector, referents for seed certification bodies, landscaping companies;

- Questionnaires conducted with ski area operators $(n=51)$ and other types of planners $(n=20)$ to get quantitative data on revegetation practices.

- Observation notes and documents collected through our participation in bodies such as committees, meetings or fieldwork days.

Seed mixtures of non-local origin are usually composed of farmer-propagated cultivar seeds developed and marketed by seed companies. Local seeds supply chains are nonetheless developing. Local seeds can be harvested directly (by brushing, aspiration or mowing) from a natural environment ecologically similar to the area to be restored, or obtained by cultivating and multiplying locally harvested mother seeds of the species of interest. These two methods involve different stakeholders: farmers, agricultural contractors and land developers for the first, seed companies and seed multiplier farmers for the second.

Because the relationship to the biodiversity enhancement differs according to the origin of seed mixtures, we splat the revegetation activity in two in order to posit it within the framework (Figure 
Ruault, J. F., la Tour, A. D., Evette, A., Allain, S., \& Callois, J. M. (2022). A biodiversity-employment framework to protect biodiversity. Ecological Economics, 191, 107238.

https://doi.org/10.1016/j.ecolecon.2021.107238

3). On the x-axis, the effect of the biodiversity enhancement on employment growth is negative in both cases, but not with the same magnitude. Although the actions deployed aim to lead to ecosystems in good condition, jobs associated to revegetation exist in the first stance due to a loss of diversity. Harvesting locally sourced seeds requires natural environments in a good biodiversity state, what counterbalances partly the negative biodiversity-employment relationship. For this reason, we attribute a lower score on the $\mathrm{x}$-axis to revegetation with non-local seeds $(-0,75)$ than with local ones (providing they come from biodiversity-harvesting or from multiplication of locally sourced mother seeds) $(-0,25)$.

When it comes to the other side of the relationship (the y-axis), scores also vary depending on whether the seeds are of local origin or not. In the short and medium term, revegetation helps to reconstitute herbaceous plants and maintain the soil in sloping environments where stakeholders need to restore certain ecosystem functions. This encourages the recolonization of the environment by other plant, animal, bacterial and mycorrhizal organisms. However, the use of non-local seeds carries the risk of the non-establishment of flora, competition or hybridization with local flora, and disruption of common cycles with other organisms such as insects (Vander Mijnsbrugge et al., 2010). Although restoration cannot return ecosystems to a 'baseline' and the precise long-term consequences are unpredictable, it is known that diverse seed mixtures of local origin can help preserve the original identity and adaptability of the vegetation. The use of locally sourced seeds, which are adapted to the environment and more genetically diverse, also allows the reconstitution of self-sustaining vegetation that better supports the return of other organisms. This is why we considered that, on reworked land where vegetation is destroyed, revegetation with non-local seeds has a slightly positive direct impact (0.25) on biodiversity, while revegetation with local seeds has a highly positive direct impact (0.75).

The general objective of revegetation is to reconstitute herbaceous plant cover. However, as the activity is necessitated by development works which destroy the herbaceous vegetation, we consider that it should be considered as part of wider activities negatively impacting biodiversity. It is generally the developers themselves who carry out or have carried out these operations, and if the revegetation can be made in other frameworks (erosion of hiking trails, debris flows), this remains exceptional. Granjou, Gaucherand et al. (2010) showed, in the case of revegetation activities in a French alpine ski resort, the potential perverse effect of an environmental discourse from developers emphasizing the repair activity, which would tend to legitimize development projects. Indeed, revegetation can be considered as a cancellation of degradation, which it is not, and this can serve as a justification for environmental damage. In authorization requests for development, revegetation operations are generally necessary to obtain permission from the authorities. Therefore, such revegetation operations can indirectly facilitate the realization of developments that impact biodiversity negatively. We found that these indirect effects occur for both types of revegetation, but in different ways. Local seeds are more complicated to utilize in terms of costs and organization; they require the cooperation of many different stakeholders, including specialized seed producers, botanists and/or ecologists. The higher cost of revegetation might, to some extent, make development plans more expensive and therefore restrict them. Moreover, the use of local seeds incites the stakeholders concerned to recognize the original flora as a heritage to be preserved and, by competing practices with non-local seeds, produces an extra positive indirect impact on biodiversity. In contrast, revegetation with non-local seeds, which is 
Ruault, J. F., la Tour, A. D., Evette, A., Allain, S., \& Callois, J. M. (2022). A biodiversity-employment framework to protect biodiversity. Ecological Economics, 191, 107238.

https://doi.org/10.1016/j.ecolecon.2021.107238

inexpensive and relatively easy to carry out, might favor development operations that lead to the destruction of native vegetation. We therefore considered that the indirect impact of revegetation on biodiversity is fairly negative for revegetation with non-local seeds (-0.5), highlighting a case of 'green job fallacy', and slightly positive for revegetation with local seeds (0.25).

However, we emphasize that the direct and indirect impacts of revegetation activities are highly difficult to assess. The level of complexity and uncertainty is high and plays a role at all stages in these ecological and social systems: the effects of ecological restoration vary from case to case, stakeholders and their management choices also depend on situations, and it is difficult to attribute a general tendency to a type of activity. The notations proposed here for revegetation are therefore to be considered with caution, with an area of validity specific to our mountain case study experience. Beyond this, the positioning exercise of revegetation with seeds of local or non-local origin allows to discuss the state of biodiversity on which the activity is based, the impact of the latter on biodiversity, and through what mediations. In light of this, the framework has a heuristic interest that goes beyond a quantitative evaluation of the activity and its different impacts on biodiversity.

\subsubsection{Case 2: guided-nature tours in the major French natural heritage sites}

Nature-based tourism is primarily concerned with the "direct enjoyment of some relatively undisturbed phenomenon of nature" (Valentine, 1992, p. 108). It encompasses activities such as wildlife watching, hiking, climbing, guided nature tours, safaris, boat cruises, sport fishing, photography, stargazing, conservation activities, scuba diving and so on. Some of these activities can take place without preserving nature, but biodiversity and related ecosystem service outputs remain an important factor in attracting tourists (e.g. scuba diving, hiking, etc.). In this context, the value of biodiversity does not necessarily come from the diversity of life itself, but often from the fact that it maintains outstanding landscapes, which attract tourists (Talandier et al., 2019). Some types of nature-based tourism focus only on access to the landscape or the discovery of nature, allowing certain excessive or damaging practices. Some researchers have thus chosen to concentrate on the impacts of nature tourism activities and their ability to coexist in a sustainable way with conservation goals (Valentine, 1992; Orams, 1996). This approach considers undesired consequences such as litter, wildlife disturbance, erosion and trampling of fragile habitats, soil artificialization for transportation infrastructure and lodging facilities, etc. Although the tourism economy is important for many regions, there are increasing cases where popular tourist sites are being closed (e.g. Aldabra Atoll in the Seychelles, Fjaorargljufur Canyon in Iceland) or restricted (e.g. Machu Picchu in Peru, Mont Blanc in France) due to over-visitation.

The present nature-based tourism case study uses the materials and accumulated experience of a three-year research project (2014-2017) aimed at identifying and describing the trade-offs between protection and economic valorisation of 70 major heritage sites of metropolitan France (i.e. UNESCO sites and "Grand Sites de France" members). The panel of sites covers a large diversity of natural heritage including for example the Puy de Dome dormant volcano, the Navacelles mountain circus, the Frehel Cape, the Pilat dune, the Verdon gorges, the Salagou Valley, the Sanguinaires islands, Porto Gulf, the Mont-Saint-Michel bay, the Causses and Cévennes agropastoral landscape and so on. The materials are the results of a mixed research method, 
Ruault, J. F., la Tour, A. D., Evette, A., Allain, S., \& Callois, J. M. (2022). A biodiversity-employment framework to protect biodiversity. Ecological Economics, 191, 107238.

https://doi.org/10.1016/j.ecolecon.2021.107238

combining the statistical typology of the different socio-economic contexts in which heritage sites take place, an online questionnaire survey of heritage site managers and exploratory field investigations of 7 areas. While not all heritage sites are concerned by guided-nature tour, the majority of natural heritage sites are, as this is one of the most common forms of reconciling the issues of site protection and economic valorisation. Guided-nature tours are typically assumed to provide positive outputs (exploring natural areas, discovering wildlife, environmental education, etc.) without causing any major damage to natural capital. However, around the world, some tours fuel the excesses of mass tourism, from overcrowding to misbehaviour, damaging the ecosystems they are meant to showcase and missing the opportunity of offering a better understanding of the living world. There are also certain periods that are more favourable for selling nature tours, and consequently seasonal peaks are accompanied by corresponding high pressure on the environment, with particular areas thronged by groups of tourists. For example, in our French case study, congestion of the Somme Bay can be observed in the summer, when groups of tourists congregate on the foreshore. Some guides may even seek to disturb certain wildlife species so they can be seen by tourists (e.g. dolphin watching in the Porto Gulf). However, the negative environmental impacts of guided nature tours are usually countered by limiting visits to a few places a few times a day. In addition, restrictions on unguided access are often in place, limiting unsupervised tourist practices. For this reason, in our analysis we considered that the direct impact of guided nature tours on biodiversity is slightly negative in France (-0.25 on the y-axis).

Furthermore, with the rise in living standards, tourism in general, including nature-based tourism, generates numerous long-distance trips that contribute to greenhouse gas emissions and ecological footprint. However, it would not be fair to attribute this social cost to guided tours, as nature-based tourism does not need guides to exist and attract tourists. In fact, guides are often useful in controlling the impact of tourism and promoting better behaviour, sometimes to the point that access to a site is closed except with a guide. Guided nature tours can then positively replace tourist practices observed in time $t$ with less impactful practices in time $t+1$ and further improve future practices in time $t+2$. All other things being equal, we considered the rise in nature-based tourism jobs in France fairly positively linked with a positive indirect impact on biodiversity $(+0.5$ on the colour gradient).

Finally, guided nature tours depend on existing biodiversity and the maintenance of ecological balance, but also offer an ability to talk about past species and ecosystems, changes to the landscape and some key popular species. The latter are often large charismatic species near the top of the food chain, which is consequently sensitive to ecological disturbance in the links below. The conservation of biodiversity in general is here often driven by the motivation to preserve flagship species (Walpole and Leader-Williams, 2002). Thus, we assumed that while growth in employment is not fully linked to enhanced biodiversity in general, it is fairly linked to the impact of enhanced biodiversity on flagship species (+0.5 on the x-axis).

\subsubsection{Case 3: Soil Bioengineering for Riverbank Protection}

Rivers naturally move laterally across the landscape and change depth vertically; these movements are important for maintaining sediment loads to avoid riverbed incision and for habitat rejuvenation to conserve biodiversity (Florsheim et al., 2008). However, as human assets are often built near 
Ruault, J. F., la Tour, A. D., Evette, A., Allain, S., \& Callois, J. M. (2022). A biodiversity-employment framework to protect biodiversity. Ecological Economics, 191, 107238.

https://doi.org/10.1016/j.ecolecon.2021.107238

rivers, this infrastructure needs to be protected against flooding and erosion. There are two main types of techniques to protect riverbanks from erosion: the most widespread is civil engineering, which includes the construction of riprap, masonry, gabion or concrete structures. The second, much rarer but expanding, is soil bioengineering, which uses living and non-living vegetation as structural engineering components in an integrated system that protects the entire riverbank (Clark and Hellin, 1996; Evette et al., 2012). Soil bioengineering techniques are nowadays present in most parts of the world as mainstream techniques in rivers of the plain. For example, a database developed in France shows more than 250 examples of such techniques (Jaymond et al. 2019). Our assessment of soil bioengineering within the biodiversity-employment framework is then based on a large collection of case studies. Furthermore the participation of one of the authors to the assessment of the biodiversity of numerous soil bioengineering works in France, Switzerland or Canada (Cavaillé, Dommanget et al. 2013, Cavaillé, Ducasse et al. 2015, Janssen, Cavaillé et al. 2019, Tisserant, Janssen et al. 2020) makes it possible to draw some conclusions and hypotheses to assess the ratings related to biodiversity-friendliness.

Figure 4. Photo of a riverbank soil bioengineering work before, during and four years after the implementation

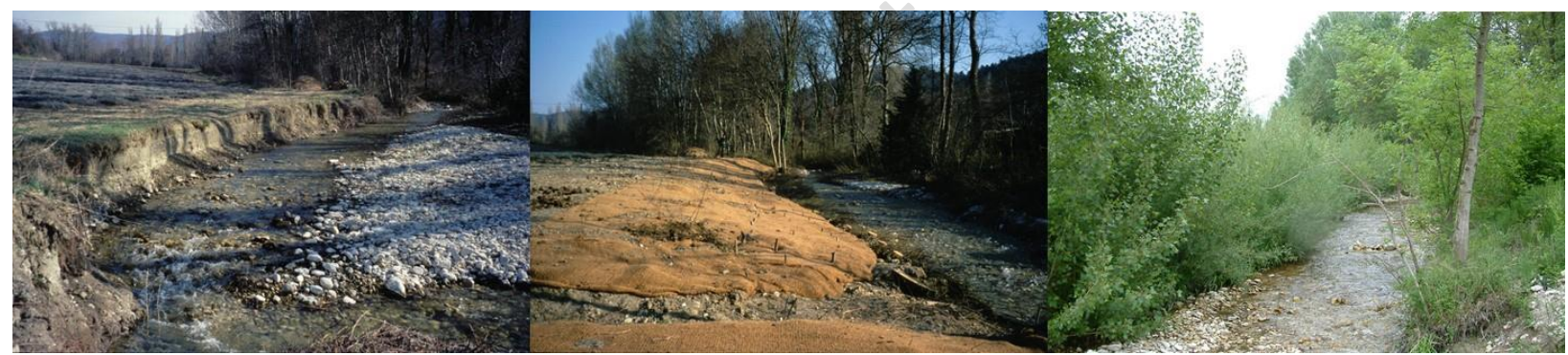

Source: (C) CFPF

Soil bioengineering techniques for riverbank protection are nature-based solutions that replicate functioning natural systems with the aim of simultaneously solving erosion issues and fulfilling ecological functions. At large spatial and temporal scales, riverbank stabilization impedes the flooding that both disturbs and rejuvenates these environments. This has the effect of preventing the creation of pioneer habitats, which tend to be rarer in heavily modified river systems (Florsheim et al., 2008), thus contributing to the reduction of biodiversity. For example, on the Isère River in Savoie, river embankments joined with riverbank protection has led to a reduction of $90 \%$ of highly disturbed habitats with its specific vegetation (Girel 2010). Compared to civil engineering solutions, however, soil bioengineering techniques enhance local plant diversity (Cavaillé et al., 2015), macro benthic diversity (Cavaillé et al., 2018), habitat quality and multitaxonomic diversity (Janssen et al., 2019). Soil bioengineering also triggers successional dynamics similar to those theoretically found under natural conditions, favouring ecological processes (Tisserant et al., 2020). Moreover, it can contribute to the restoration of ecological corridors (Martin et al., 2020). All of these aspects clearly show that soil bioengineering techniques promote local plant and animal biodiversity by providing natural - ideally native - vegetation cover. 
Ruault, J. F., la Tour, A. D., Evette, A., Allain, S., \& Callois, J. M. (2022). A biodiversity-employment framework to protect biodiversity. Ecological Economics, 191, 107238.

https://doi.org/10.1016/j.ecolecon.2021.107238

Considering soil bioengineering as an economic activity, its growth should therefore trigger an improvement in local biodiversity. This is particularly the case because such techniques are frequently used on low-biodiversity riverbanks, degraded by erosion and/or artificialization (including civil engineering flood protection structures). For example, the soil bioengineering bank presented on

Figure 4 has tremendously increased the biodiversity supported by the bank. Despite the disturbances to biodiversity due to riverbank stabilization in general, the fact that soil engineering works are carried out on degraded banks in most cases leads us to estimate that the direct impact of the growth of bioengineering activity on biodiversity is fairly positive $(+0.5$ on the y-axis). Whenever soil bioengineering works are part of land development projects and settle on natural habitats (e.g. securing the course of a river to allow the construction of infrastructure), then the direct impact on biodiversity would be highly negative (-0.75) as it would replace a settled riverbank ecosystem with a new ecosystem created to fulfil land protection functions as a priority at the expense of the former ecological functions.

While implementing soil bioengineering techniques tends to improve local biodiversity, this depends on overall existing biodiversity. These nature-based solutions may use autochthonous living seeds, parts of plants and nearby plant communities that are already adapted to the site conditions (Zeh, 2007; Hoerbinger and Rauch, 2019). For instance, to restore the riverbanks following the construction of a hydroelectric dam along the Romanche River in the French Alps, $1.6 \mathrm{~km}$ of soil bioengineering techniques were implemented on both banks of the river. A local seed mixture was first harvested in meadows in the surrounding area, and then sown on the works (Weissgerber et al., 2019). A total of 38 ligneous plantings and cuttings, harvested locally, have been planted on the works (Delage, Evette et al. 2017). Sometimes it may also be necessary to use non-native plants, such as drought-resistant species, due to climate change, for example (Weissgerber et al., 2019). For both biodiversity restoration and structural resistance, it is recommended using a wide variety of species as seedlings, as well as shrubs and trees. Despite these benefits of soil bioengineering, it remains an activity that primarily addresses needs arising from environmental degradation; the decrease in biodiversity along degraded riverbanks due to anthropization is expected to lead to an increase in the need for an ecological restoration. For instance, along the Yzeron River, a small tributary of the Rhône River in Lyon conurbation, the bed and riverbanks were completely concreted. Riverbanks were then restored using some soil bioengineering techniques (Cottet, Augendre et al. 2015).

Thus, as this activity that mostly arises from a degradation of biodiversity, we considered the direct impact of the biodiversity enhancement on the economic activity fairly negative $(-0.5$ on the $\mathrm{x}$ axis), although the expansion of restoration measures is possible as long as there is a sufficient supply of plant material (too much degradation would lead to less suitable techniques of poorer quality).

Riverbank protection secures important economic assets and human population safety, making them de rigueur for the most part. Under this assumption that bioengineering has little or no influence on the emergence of land development and riverbank protection requirements, it is then the ecologically better alternative to civil engineering (e.g. riprap) by enhancing local animal and plant biodiversity on degraded or new banks. We therefore considered the indirect impact of 
Ruault, J. F., la Tour, A. D., Evette, A., Allain, S., \& Callois, J. M. (2022). A biodiversity-employment framework to protect biodiversity. Ecological Economics, 191, 107238.

https://doi.org/10.1016/j.ecolecon.2021.107238

bioengineering employment growth on biodiversity to be highly positive ( 0.75 on the colour gradient).

In conclusion, the social-ecological framework makes possible to question the global relationship between soil bioengineering techniques and biodiversity. It goes further than comparing restored river with non-restored or rip rapped riverbanks as it is most frequently done (Schmitt, Schäffer et al. 2018, Martin, Janssen et al. 2020). Degradation of the ecosystem is a process acting at multiple scales: riverbank restoration through soil bioengineering techniques will be an improvement at a local scale (e.g. bank), but it may contribute to reducing biodiversity at a larger scale (e.g. reach or watershed) by impeding erosion from flood disturbance and then the creation of new juvenile habitat. 
Ruault, J. F., la Tour, A. D., Evette, A., Allain, S., \& Callois, J. M. (2022). A biodiversity-employment framework to protect biodiversity. Ecological Economics, 191, 107238.

https://doi.org/10.1016/j.ecolecon.2021.107238

\section{Discussion and Conclusion}

The debate on green jobs is generally focusing on accounting issues: how many jobs are green, which metrics should be used, how to increase the number of green jobs. Different policy frameworks underlie these questions, such as that of "inclusive green growth" or "sustainable development": they have in common to take the deployment of green jobs as inherently desirable, hence deserving political encouragement, generally in the form of economic incentives. This paper has the respect of planetary boundaries as a final objective, and the deployment of green jobs only as a possible - yet not granted - means towards this aim. Indeed, we posit that it is critical today to deepen the reflection about which jobs belong more to the problem and which more to the solution of the ecological crisis. In trying so, economists ineluctably face the complexity of socialecological relationships: often non-linear, cascading and cross-scalar, hence producing complex, multiple, and not always direct relationships between employment and biodiversity. The framework we chose to develop, certainly simplified, has the peculiarity of addressing socialecological feedbacks and indirect effects, in a perspective where biodiversity protection is a prerequisite for social welfare.

Our framework makes it possible to distinguish shades of green, but also more importantly idealtypes of jobs according to their biodiversity-employment relationships. The framework could also be adapted to other sustainable development goals (e.g. climate change, clean energy...), but because it is still challenging to elucidate if and when SDG mutually enhance each other vs when they generate trade-offs, we preferred to focus solely, as a start, on biodiversity protection. This bias should not mask the need for continuous efforts to tackle the complex relationships between environmental dimensions, e.g. nexus approaches (Bazilian et al., 2011).

We derive two main insights from the framework. The first one stems from positioning specific jobs (i.e. case studies) in the grid. Despite the lack or heterogeneity of available data, it was, however, possible to attribute scores to the different jobs under scrutiny. The interest of the exercise was not so much the final score, but the reflection it required from authors in charge of the expertise. For instance, further refinements in jobs' partitioning was needed in two case studies, depending on the chain of activities in which develops a specific job and the substrate (e.g. a loss of biodiversity) on which the activity grows. The exercise also highlights that there are probably no "purely green" jobs, as many introduce drawbacks, although of less importance than their benefits to biodiversity. Current knowledge on biodiversity-employment relationship is unequal and mainly oriented towards direct impacts on biodiversity. Further research and indicator developments could help clarify more complex biodiversity-employment relationships.

The second insight comes from the use of the framework for policy design. The framework can help analyse biodiversity-employment relationships in macroscopic and dynamic terms, by considering the evolution of job positions across quadrants. Also, and this is one of our main arguments, the frameworks highlights that economic incentives are not necessarily suited to every kind of job; worse, they can even generate perverse or fallacious effects. What we call the "green job fallacy" lies for a large part in the legitimation offered by offsetting options to biodiversitydestructive activities, welcoming jobs that respond to a trend of damage to the biosphere rather 
Ruault, J. F., la Tour, A. D., Evette, A., Allain, S., \& Callois, J. M. (2022). A biodiversity-employment framework to protect biodiversity. Ecological Economics, 191, 107238.

https://doi.org/10.1016/j.ecolecon.2021.107238

than contribute to a sound and sustainable economic pathway. The rhetoric of co-benefits may be an incentive for land development projects, as the latter can claim for a "no net loss of biodiversity" providing offsetting measures, with the added argument of creating new jobs. We hypothesize that the success of this "win-win" rhetoric comes from its social acceptability and fit with the dominant economic paradigm, while assuming incommensurable trade-offs and accompanying the decline of some activities for the sake of biodiversity would be politically risky. For some of the biodiversity-employment configurations we highlighted, public and international institutions (e.g. governments, intergovernmental organisations...) constitute, however, the last rampart against biodiversity loss. In any case, laws, police and justice, citizen education and environmental ethic promotion are non-optional instruments to achieve an effective transition towards sustainable economies.

We therefore support the call of Ostrom and Cox (2010, p. 460) to move beyond simple panaceas and blueprints in order to "overcome overly simplified responses to serious environmental problems". Green job policies should be vigilant about their environmental effectiveness and include outcome monitoring, in order to check that the cure is not worse than the disease. In our opinion, this implies - at least - three directions in the future. First, remedying the loss of ecological knowledge that occurs with the industrialization of societies (Pilgrim et al., 2008) in order to foster social learning on Human-Nature relationships in general, and biodiversityemployment relationship in particular. Second, the recourse to ecological sensors should be encouraged, by spreading the use of indicators (e.g. ecological footprint), but mostly by developing "an infrastructure of sensors that allows tracking the time-lag between environmental changes and reactions of societies" (Lenton and Latour, 2018, p. 1068). These sensors would help create the self-regulatory mechanisms necessary to refrain the vicious circles of "biodiversity depletion $\rightarrow$ substitute technologies and activities (more "biodiversity depletion"). Lastly, the development of approaches aimed at revealing trade-offs among SDGs, such as nexus and inclusive development approaches (Gupta and Vegelin, 2016), would help re-politicize the questions of resources for biodiversity conservation and role of employment in society. 
Ruault, J. F., la Tour, A. D., Evette, A., Allain, S., \& Callois, J. M. (2022). A biodiversity-employment framework to protect biodiversity. Ecological Economics, 191, 107238.

https://doi.org/10.1016/j.ecolecon.2021.107238

\section{References}

Aceleanu, M., 2015. Green jobs in a green economy: Support for a sustainable development 9, 341-355. https://doi.org/10.1504/PIE.2015.076894

Ament, J., 2020. An ecological monetary theory. Ecological Economics 171, 106421. https://doi.org/10.1016/j.ecolecon.2019.106421

Antal, M., 2014. Green goals and full employment: Are they compatible? Ecological Economics 107, 276286. https://doi.org/10.1016/j.ecolecon.2014.08.014

Bain, P.G., Milfont, T.L., Kashima, Y., Bilewicz, M., Doron, G., Garđarsdóttir, R.B., Gouveia, V.V., Guan, Y., Johansson, L.-O., Pasquali, C., Corral-Verdugo, V., Aragones, J.I., Utsugi, A., Demarque, C., Otto, S., Park, J., Soland, M., Steg, L., González, R., Lebedeva, N., Madsen, O.J., Wagner, C., Akotia, C.S., Kurz, T., Saiz, J.L., Schultz, P.W., Einarsdóttir, G., Saviolidis, N.M., 2016. Co-benefits of addressing climate change can motivate action around the world. Nature Climate Change 6, 154-157. https://doi.org/10.1038/nclimate2814

Barbier, E.B., 2016. Building the Green Economy. Canadian Public Policy / Analyse de Politiques 42, S1-S9.

Bastiat, F. (2007). Bastiat Collection, The. Ludwig von Mises Institute.

Bazilian, M., Rogner, H., Howells, M., Hermann, S., Arent, D., Gielen, D., ... Yumkella, K. K. (2011). Considering the energy, water and food nexus: Towards an integrated modelling approach. Energy Policy, 39(12), 7896-7906. doi: 10.1016/j.enpol.2011.09.039

Becker, R.A., Shadbegian, R.J., 2009. Environmental Products Manufacturing: A Look inside the Green Industry. The B.E. Journal of Economic Analysis \& Policy 9. https://doi.org/10.2202/1935-1682.2117

Beir, J.D., Emond, C., L'Horty, Y., Tuffery, L., 2017. Protecting biodiversity by developing bio-jobs: a multibranch analysis with an illustration using French data. International Journal of Sustainable Development 20, 306-323. https://doi.org/10.1504/IJSD.2017.090006

Beketov, M.A., Kefford, B.J., Schäfer, R.B., Liess, M., 2013. Pesticides reduce regional biodiversity of stream invertebrates. PNAS 110, 11039-11043. https://doi.org/10.1073/pnas.1305618110

Berkes, F., Folke, C., Colding, J., 2000. Linking Social and Ecological Systems: Management Practices and Social Mechanisms for Building Resilience. Cambridge University Press.

Bischoff, A., Steinger, T., Müller-Schärer, H., 2010. The Importance of Plant Provenance and Genotypic Diversity of Seed Material Used for Ecological Restoration. Restoration Ecology 18, 338-348. https://doi.org/10.1111/j.1526-100X.2008.00454.x

Boeraeve, F., Dendoncker, N., Jacobs, S., Gómez-Baggethun, E., Dufrêne, M., 2015. How (not) to perform ecosystem service valuations: pricing gorillas in the mist. Biodivers Conserv 24, 187-197. https://doi.org/10.1007/s10531-014-0796-1

Bowen, A., Kuralbayeva, K., 2015. Looking for green jobs: the impact of green growth on employment. Global Green Growth Institute.

Brundland, G., 1987. Our Common Future. World Commission on Environment and Development. 
Ruault, J. F., la Tour, A. D., Evette, A., Allain, S., \& Callois, J. M. (2022). A biodiversity-employment framework to protect biodiversity. Ecological Economics, 191, 107238.

https://doi.org/10.1016/j.ecolecon.2021.107238

Cai, W., Wang, C., Chen, J., Wang, S., 2011. Green economy and green jobs: Myth or reality? The case of China's power generation sector. Energy 36, 5994-6003. https://doi.org/10.1016/j.energy.2011.08.016

Callois, J.M., 2017. Biodiversity and economic development: the impacts of ecological offset policies on local development. Sciences Eaux \& Territoires 2017, 7 p. https://doi.org/10.14758/SETREVUE.2017.HS.04

Cavaillé, P., F. Dommanget, N. Daumergue, G. Loucougaray, T. Spiegelberger, E. Tabacchi and A. Evette (2013). "Biodiversity assessment following a naturality gradient of riverbank protection structures in French prealps rivers." Ecological Engineering 53(0): 23-30.

Cavaillé, P., Ducasse, L., Breton, V., Dommanget, F., Tabacchi, E., Evette, A., 2015. Functional and taxonomic plant diversity for riverbank protection works: Bioengineering techniques close to natural banks and beyond hard engineering. Journal of Environmental Management 151, 65-75. https://doi.org/10.1016/j.jenvman.2014.09.028

Cavaillé, P., Dumont, B., Van Looy, K., Floury, M., Tabacchi, E., Evette, A., 2018. Influence of riverbank stabilization techniques on taxonomic and functional macro benthic communities. Hydrobiologia 807 , 19-35. https://doi.org/10.1007/s10750-017-3380-3

CGDD, 2019. Les éco-activités et l'emploi environnemental en 2017 : premiers résultats. Paris.

Chapin lii, F.S., Zavaleta, E.S., Eviner, V.T., Naylor, R.L., Vitousek, P.M., Reynolds, H.L., Hooper, D.U., Lavorel, S., Sala, O.E., Hobbie, S.E., Mack, M.C., Díaz, S., 2000. Consequences of changing biodiversity. Nature 405, 234-242. https://doi.org/10.1038/35012241

Clark, J., Hellin, J., 1996. Bio-engineering for effective road maintenance in the Caribbean.

Costanza, R., d'Arge, R., Groot, R. de, Farber, S., Grasso, M., Hannon, B., Limburg, K., Naeem, S., O'Neill, R.V., Paruelo, J., Raskin, R.G., Sutton, P., Belt, M. van den, 1997. The value of the world's ecosystem services and natural capital. Nature 387, 253. https://doi.org/10.1038/387253a0

Cottet, M., M. Augendre, D. Roux-Michollet and H. Tronchere (2015). My river is not your river: resident and expert values associated with an urban river in a restoration context (Yzeron River, France). Ecohydrology'2015: Measuring, Modeling and Managing of the natural processes related to water flows, Social values of the linked ecosystem services.

Delage, C., A. Evette, N. Daumergue, G. Huyghe and F. Jacob (2017). "Évaluation de la réussite de l'ouvrage de protection de berges de la Romanche au barrage de Livet, réalisé à l'aide de techniques de génie végétal." Sciences Eaux \& Territoires Hors Série (36): 6.

Dirzo, R., Young, H.S., Galetti, M., Ceballos, G., Isaac, N.J.B., Collen, B., 2014. Defaunation in the Anthropocene. Science 345, 401-406. https://doi.org/10.1126/science.1251817

Drews, S., Savin, I., van den Bergh, J.C., 2019. Opinion Clusters in Academic and Public Debates on Growthvs-Environment. Ecological Economics 157, 141-155.

Dupré la Tour, A., Labatut, J., Spiegelberger, T., 2018. Pratiques de revégétalisation de milieux ouverts et perspectives pour la constitution d'une filière de semences d'origine locale en montagne alpine. Fourrages 269-274. 
Ruault, J. F., la Tour, A. D., Evette, A., Allain, S., \& Callois, J. M. (2022). A biodiversity-employment framework to protect biodiversity. Ecological Economics, 191, 107238.

https://doi.org/10.1016/j.ecolecon.2021.107238

Ekins, P., Simon, S., Deutsch, L., Folke, C., De Groot, R., 2003. A framework for the practical application of the concepts of critical natural capital and strong sustainability. Ecological Economics, Identifying Critical Natural Capital 44, 165-185. https://doi.org/10.1016/S0921-8009(02)00272-0

Elliott, R.J.R., Lindley, J.K., 2017. Environmental Jobs and Growth in the United States. Ecological Economics 132, 232-244. https://doi.org/10.1016/j.ecolecon.2016.09.030

Evette, A., Balique, C., Lavaine, C., Rey, F., Prunier, P., 2012. Using Ecological and Biogeographical Features to Produce a Typology of the Plant Species Used in Bioengineering for Riverbank Protection in Europe. River Research and Applications 28, 1830-1842. https://doi.org/10.1002/rra.1560

Fisher, B., Turner, R.K., Morling, P., 2009. Defining and classifying ecosystem services for decision making. Ecological Economics 68, 643-653. https://doi.org/10.1016/j.ecolecon.2008.09.014

Florsheim, J.L., Mount, J.F., Chin, A., 2008. Bank Erosion as a Desirable Attribute of Rivers. BioScience 58, 519-529. https://doi.org/10.1641/B580608

Folke, C., Pritchard, J., Berkes, F., Colding, J., Svedin, U., 2007. The Problem of Fit between Ecosystems and Institutions: Ten Years Later. Ecology and Society 12. https://doi.org/10.5751/ES-02064-120130

Forstater, M., 2006. Green Jobs: Public Service Employment and Environmental Sustainability. Challenge 49, 58-72. https://doi.org/10.2753/CHA0577-5132490405

Forstater, M., 2004. Green jobs: addressing the critical issues surrounding the environment, workplace, and employment. International Journal of Environment, Workplace and Employment 1, 53-61.

Gallai, N., Vaissière, B., 2009. Guidelines for the economic valuation of pollination services at a national scale. Guidelines for the economic valuation of pollination services at a national scale, FAO (2009).

Georgescu-Roegen, N., 1993. The entropy law and the economic problem. Valuing the earth: Economics, ecology, ethics 75-88.

Granjou C., Gaucherand S., Chanteloup E., 2010. De la réparation à la restauration. La revégétalisation des pistes de ski à l'Alpe d'Huez. Journal of Alpine Research| Revue de géographie alpine (98-3) (2010)

Gupta J., Vegelin C. (2016). Sustainable development goals and inclusive development. International environmental agreements: Politics, law and economics (16(3)) (2016), pp. 433-448, 10.1007/s10784016-9323-z

Hatt, S., Osawa, N., 2019. Beyond "greening": which paradigms shape sustainable pest management strategies in the European Union? BioControl 64, 343-355. https://doi.org/10.1007/s10526-01909947-z

Helm, D., Hepburn, C. (Eds.), 2014. Nature in the Balance: The Economics of Biodiversity. Oxford University Press, Oxford, New York.

Hoerbinger, S., Rauch, H.P., 2019. A Case Study: The Implementation of a Nature-Based Engineering Solution to Restore a Fallopia japonica-Dominated Brook Embankment. Open Journal of Forestry 9, 183-194.

Holling, C.S., 2001. Understanding the complexity of economic, ecological, and social systems. Ecosystems 4, 390-405.

Hughes, G., 2011. The myth of green jobs. Global Warming Policy Foundation. 
Ruault, J. F., la Tour, A. D., Evette, A., Allain, S., \& Callois, J. M. (2022). A biodiversity-employment framework to protect biodiversity. Ecological Economics, 191, 107238.

https://doi.org/10.1016/j.ecolecon.2021.107238

International Labour Office, 2018. World employment and social outlook 2018: Greening with jobs. ILO Geneva.

International Labour Office, 2019. World employment and social outlook: Trends 2018. Geneva, Switzerland.

Janssen, P., Cavaillé, P., Bray, F., Evette, A., 2019. Soil bioengineering techniques enhance riparian habitat quality and multi-taxonomic diversity in the foothills of the Alps and Jura Mountains. Ecological Engineering 133, 1-9. https://doi.org/10.1016/j.ecoleng.2019.04.017

Jaymond D., Evette A., Bray F., Leblois L., Jung D., Vivier A., Dorget C., 2021. BD GeniVeg : une base de données française sur les ouvrages de protection de berges en génie vegetal. Sciences Eaux \& Territoires (Hors série 78) (2021), pp. 1-6

Kiehl, K., Kirmer, A., Donath, T.W., Rasran, L., Hölzel, N., 2010. Species introduction in restoration projects-Evaluation of different techniques for the establishment of semi-natural grasslands in Central and Northwestern Europe. Basic and Applied Ecology 11, 285-299. https://doi.org/10.1016/j.baae.2009.12.004

Kim, K.-H., Kabir, E., Jahan, S.A., 2017. Exposure to pesticides and the associated human health effects. Sci Total Environ 575, 525-535. https://doi.org/10.1016/j.scitotenv.2016.09.009

Kinzig, A.P., Ryan, P.A., Etienne, M., Allison, H.E., Elmqvist, T., Walker, B.H., 2006. Resilience and regime shifts: assessing cascading effects. Ecology and Society 11.

Lascoumes, P., Gales, P.L., 2007. Introduction: Understanding Public Policy through Its Instruments-From the Nature of Instruments to the Sociology of Public Policy Instrumentation. Governance 20, 1-21. https://doi.org/10.1111/j.1468-0491.2007.00342.x

Lenton, T.M., Latour, B., 2018. Gaia 2.0. Science 361, 1066-1068.

Levin, S., Xepapadeas, T., Crépin, A.-S., Norberg, J., Zeeuw, A. de, Folke, C., Hughes, T., Arrow, K., Barrett, S., Daily, G., Ehrlich, P., Kautsky, N., Mäler, K.-G., Polasky, S., Troell, M., Vincent, J.R., Walker, B., 2013. Social-ecological systems as complex adaptive systems: modeling and policy implications. Environment and Development Economics 18, 111-132. https://doi.org/10.1017/S1355770X12000460

Levrel, H., 2020. D’une économie de la biodiversité à une économie de la conservation de la biodiversité. Fondation pour la Recherche sur la biodiversité, juin.

Liu, J., Dietz, T., Carpenter, S.R., Alberti, M., Folke, C., Moran, E., Pell, A.N., Deadman, P., Kratz, T., Lubchenco, J., Ostrom, E., Ouyang, Z., Provencher, W., Redman, C.L., Schneider, S.H., Taylor, W.W., 2007. Complexity of Coupled Human and Natural Systems. Science 317, 1513-1516. https://doi.org/10.1126/science.1144004

Maron, M., R.J. Hobbs, A. Moilanen, et al. 2012. Faustian Bargains? Restoration Realities in the Context of Biodiversity Offset Policies. Biological Conservation 155. Scopus: 141-148.

Martin, F.-M., P. Janssen, L. Bergès, B. Dupont and A. Evette (2020). "Higher structural connectivity and resistance against invasions of soil bioengineering over hard-engineering for riverbank stabilisation." Wetlands Ecology and Management. 
Ruault, J. F., la Tour, A. D., Evette, A., Allain, S., \& Callois, J. M. (2022). A biodiversity-employment framework to protect biodiversity. Ecological Economics, 191, 107238.

https://doi.org/10.1016/j.ecolecon.2021.107238

McDonald T., Gann G.D., Jonson J., Dixon K.W., 2016. International standards for the practice of ecological restoration - including principles and key concepts, Society for Ecological Restoration, Washington, DC.

Meda, D., Vendramin, P., 2016. Reinventing Work in Europe: Value, Generations and Labour, 2017 ed. ed. Springer International Publishing AG, New York, NY.

Meehan, T.D., Werling, B.P., Landis, D.A., Gratton, C., 2011. Agricultural landscape simplification and insecticide use in the Midwestern United States. PNAS 108, 11500-11505. https://doi.org/10.1073/pnas.1100751108

Michaels, R., Murphy, R.P., 2009. Green jobs: fact or fiction. Institute for Energy Research, Houston, Texas, January 1-15.

Morris, A.P., Bogart, W.T., Dorchak, A., Meiners, R.E., 2009. Green jobs myths. Mo. Envtl. L. \& Pol'y Rev. $16,326$.

MTES, 2016. Le service de pollinisation.

Muro, M., Rothwell, J., Saha, D., 2011. Sizing the Clean Economy: A National and Regional Green Jobs Assessment.

Neumayer, E., 2003. Weak Versus Strong Sustainability: Exploring the Limits of Two Opposing Paradigms. Edward Elgar Publishing.

Neuwahl, F., Löschel, A., Mongelli, I., Delgado, L., 2008. Employment impacts of EU biofuels policy: Combining bottom-up technology information and sectoral market simulations in an input-output framework. Ecological Economics 68, 447-460. https://doi.org/10.1016/i.ecolecon.2008.04.018

Norse, E.A., Brooke, S., Cheung, W.W.L., Clark, M.R., Ekeland, I., Froese, R., Gjerde, K.M., Haedrich, R.L., Heppell, S.S., Morato, T., Morgan, L.E., Pauly, D., Sumaila, R., Watson, R., 2012. Sustainability of deepsea fisheries. Marine Policy 36, 307-320. https://doi.org/10.1016/j.marpol.2011.06.008

Novello, A., Carlock, G., 2019. Redefining Green Jobs For a Sustainable Economy. The Century Foundation.

Oliver, T.H., Heard, M.S., Isaac, N.J.B., Roy, D.B., Procter, D., Eigenbrod, F., Freckleton, R., Hector, A., Orme, C.D.L., Petchey, O.L., Proença, V., Raffaelli, D., Suttle, K.B., Mace, G.M., Martín-López, B., Woodcock, B.A., Bullock, J.M., 2015. Biodiversity and Resilience of Ecosystem Functions. Trends in Ecology \& Evolution 30, 673-684. https://doi.org/10.1016/j.tree.2015.08.009

Orams, M.B., 1996. Using Interpretation to Manage Nature-based Tourism. Journal of Sustainable Tourism 4, 81-94. https://doi.org/10.1080/09669589608667260

Ostrom, E., 2011. Background on the Institutional Analysis and Development Framework. Policy Studies Journal 39, 7-27. https://doi.org/10.1111/j.1541-0072.2010.00394.x

Ostrom, E., Cox, M., 2010. Moving beyond panaceas: a multi-tiered diagnostic approach for socialecological analysis. Environmental Conservation 37, 451-463. https://doi.org/10.1017/S0376892910000834

Pereira, H.M., Ferrier, S., Walters, M., Geller, G.N., Jongman, R.H.G., Scholes, R.J., Bruford, M.W., Brummitt, N., Butchart, S.H.M., Cardoso, A.C., Coops, N.C., Dulloo, E., Faith, D.P., Freyhof, J., Gregory, R.D., Heip, C., Höft, R., Hurtt, G., Jetz, W., Karp, D.S., McGeoch, M.A., Obura, D., Onoda, Y., Pettorelli, N., Reyers, B., Sayre, R., Scharlemann, J.P.W., Stuart, S.N., Turak, E., Walpole, M., Wegmann, M., 2013. Essential Biodiversity Variables. Science 339, 277-278. https://doi.org/10.1126/science.1229931 
Ruault, J. F., la Tour, A. D., Evette, A., Allain, S., \& Callois, J. M. (2022). A biodiversity-employment framework to protect biodiversity. Ecological Economics, 191, 107238.

https://doi.org/10.1016/j.ecolecon.2021.107238

Petherick, A., 2008. Agriculture unaffected by pollinator declines. Nature news.2008.1175. https://doi.org/10.1038/news.2008.1175

Pilgrim, S.E., Cullen, L.C., Smith, D.J., Pretty, J., 2008. Ecological Knowledge is Lost in Wealthier Communities and Countries. Environ. Sci. Technol. 42, 1004-1009. https://doi.org/10.1021/es070837v

Pop, O., Dina, G.C., Martin, C., 2011. Promoting the corporate social responsibility for a green economy and innovative jobs. Procedia-Social and Behavioral Sciences 15, 1020-1023.

Potts, S.G., Neumann, P., Vaissière, B., Vereecken, N.J., 2018. Robotic bees for crop pollination: Why drones cannot replace biodiversity. Science of The Total Environment 642, 665-667. https://doi.org/10.1016/j.scitotenv.2018.06.114

Robinson, R.A., Sutherland, W.J., 2002. Post-war changes in arable farming and biodiversity in Great Britain. Journal of Applied Ecology 39, 157-176. https://doi.org/10.1046/j.1365-2664.2002.00695.x

Rockström, J., Steffen, W., Noone, K., Persson, Å., Chapin, F.S., Lambin, E., Lenton, T.M., Scheffer, M., Folke, C., Schellnhuber, H.J., Nykvist, B., de Wit, C.A., Hughes, T., van der Leeuw, S., Rodhe, H., Sörlin, S., Snyder, P.K., Costanza, R., Svedin, U., Falkenmark, M., Karlberg, L., Corell, R.W., Fabry, V.J., Hansen, J., Walker, B., Liverman, D., Richardson, K., Crutzen, P., Foley, J., 2009. Planetary Boundaries: Exploring the Safe Operating Space for Humanity. Ecology and Society 14.

Rusch, A., Chaplin-Kramer, R., Gardiner, M.M., Hawro, V., Holland, J., Landis, D., Thies, C., Tscharntke, T., Weisser, W.W., Winqvist, C., Woltz, M., Bommarco, R., 2016. Agricultural landscape simplification reduces natural pest control: A quantitative synthesis. Agriculture, Ecosystems \& Environment 221, 198-204. https://doi.org/10.1016/j.agee.2016.01.039

Schmid, E., Sinabell, F., Hofreither, M.F., 2007. Phasing out of environmentally harmful subsidies: Consequences of the 2003 CAP reform. Ecological Economics 60, 596-604. https://doi.org/10.1016/j.ecolecon.2005.12.017

Schmitt, K., M. Schäffer, J. Koop and L. Symmank (2018). "River bank stabilisation by bioengineering: potentials for ecological diversity." Journal of Applied Water Engineering and Research 6(4): 262-273.

Smith, A., Stirling, A., 2010. The Politics of Social-ecological Resilience and Sustainable Socio-technical Transitions. Ecology and Society 15. https://doi.org/10.5751/ES-03218-150111

Sulich, A., Rutkowska, M., Popławski, Ł., 2020. Green jobs, definitional issues, and the employment of young people: An analysis of three European Union countries. Journal of Environmental Management 262, 110314. https://doi.org/10.1016/j.jenvman.2020.110314

Sulich, A., Zema, T., 2018. Green jobs, a new measure of public management and sustainable development. $18,69-75$. https://doi.org/10.14712/23361964.2018.10

Talandier, M., Navarre, F., Cormier, L., Landel, P.-A., Ruault, J.-F., Senil, N., 2019. Outstanding Heritage Sites: A ressource for territories. PUCA.

TEEB 2013. Natural Capital at Risk: The Top 100 Externalities of Business. TEEB, Geneva.

Tisserant, M., Janssen, P., Evette, A., González, E., Cavaillé, P., Poulin, M., 2020. Diversity and succession of riparian plant communities along riverbanks bioengineered for erosion control: a case study in the foothills of the Alps and the Jura Mountains. Ecological Engineering 152, 105880. 
Ruault, J. F., la Tour, A. D., Evette, A., Allain, S., \& Callois, J. M. (2022). A biodiversity-employment framework to protect biodiversity. Ecological Economics, 191, 107238.

https://doi.org/10.1016/j.ecolecon.2021.107238

Valentine, P., 1992. Review: nature-based tourism, in: Weiler, B., Hall, C.M. (Eds.), Special Interst Tourism. Belhaven Press, London, Great Britain, pp. 105-127.

Vander Mijnsbrugge, K., Bischoff, A., Smith, B., 2010. A question of origin: Where and how to collect seed for ecological restoration. Basic and Applied Ecology 11, 300-311. https://doi.org/10.1016/j.baae.2009.09.002

Vona, F., Marin, G., Consoli, D., 2019. Measures, drivers and effects of green employment: evidence from U.S. local labor markets, 2006-2014. J Econ Geogr 19, 1021-1048. https://doi.org/10.1093/jeg/lby038

Walpole, M.J., Leader-Williams, N., 2002. Tourism and flagship species in conservation. Biodiversity and Conservation 11, 543-547. https://doi.org/10.1023/A:1014864708777

Weissgerber, M., Jaunatre, R., Dommanget, F., Jacob, F., Huyghe, G., Evette, A., 2019. Seeding Dynamics from a Local Seed Mixture on a Bioengineered Riverbank Protection Structure. Environmental management 64, 178-189.

Yi, H., 2013. Clean energy policies and green jobs: An evaluation of green jobs in U.S. metropolitan areas. Energy Policy 56, 644-652. https://doi.org/10.1016/j.enpol.2013.01.034

Zeh, H., 2007. Génie biologique, manuel de construction (guide publié en 5 langues). Société suisse du génie biologique et Fédération européenne pour le génie biologique.

Zuindeau, B., 2007. Territorial Equity and Sustainable Development. environ values 16, 253-268. https://doi.org/10.3197/096327107780474564Aceleanu, M., 2015. Green jobs in a green economy: Support for a sustainable development 9, 341-355. https://doi.org/10.1504/PIE.2015.076894

\section{Acknowledgements}

The authors are a mixed collective of economists and ecologists who have developed an interdisciplinary expertise to build the biodiversity-employment framework and test it applications through three case studies. J-M C. initiated the first reflections on the relationship between biodiversity and sectoral employment and encouraged J-F R. to pick up the torch. J-F R. wrote the theoretical demonstration and developed the biodiversity-employment framework, with significant inputs from S A. in the revision stages. A. E. wrote and expertly reviewed the soil bioengineering for the protection of existing riverbanks case study, A D. and JF R. do the same respectively for the mountain revegetation and the guided nature tours case studies.

All co-authors reviewed the paper and contributed to its revision. We would also like to thank Isabelle Boulangeat and Yves Schaeffer for their helpful discussions. 